\title{
LAW AND IDEOLOGY: CRITICAL EXPLORATIONS
}

\author{
Rafal Mańko* \\ Michat Stambulski**
}

According to Polish legal theorist Marek Zirk-Sadowski, the philosophy of law as a discipline can be approached from two distinct directions: either from the direction moving 'from law to philosophy', whereby lawyers try to answer the fundamental questions of jurisprudence by theorising on the basis of legal experience, or, in the opposite direction, that is 'from philosophy to law', whereby a certain philosopher or philosophical school is 'applied' to the legal field. ${ }^{1}$ Within the second paradigm of legal philosophy, in recent years there has been a growing tendency to analyse the implications of postmodernism, posthumanism ${ }^{2}$, or postructuralism upon the legal domain. Specialised volumes analysing the potential inspiration that can be drawn by critical lawyers from the works of such philosophers as Althusser, Deleuze and Gattari, Lefebvre, Agamben have been recently published. ${ }^{3}$ Most recently, even a volume on Žižek and Law came out. ${ }^{4}$

This special edition of the Wrockaw Review of Law, Administration and Economics brings together a number of papers in which Polish and foreign scholars, both emergent and established, approach the topic of the

DOI: $10.1515 /$ wrlae-2015-0019

* Ph.D. in law (University of Amsterdam); external fellow at the Centre for the Study of European Contract Law (CSECL), University of Amsterdam. The views expressed in this paper do not represent the position of any institution.

** Centre for Legal Education and Social Theory, Faculty of Law, Administration and Economics, University of Wrocław.

${ }^{1}$ Marek Zirk-Sadowski, Wprowadzenie do filozofii prawa [An Introduction to the Philosophy of Law] (Warszawa, Wolters Kluwer 2011).

${ }^{2}$ See especially Adam Sulikowski, Posthumanizm a prawoznawstwo [Posthumanism and Jurisprudence] (Opole, Wydawnictwo Uniwersytetu Opolskiego 2013).

${ }^{3}$ See inter alia: A. Hunt \& G. Wickham, Foucault and Law: Towards a Sociology of Law as Governance (London-Chicago, Pluto Press 1994, repr. 1998); P. Goodrich, F. Hoffmann, M. Rosenfeld \& C.Vismann (eds), Derrida and Legal Philosophy (Houndmills, Palgrave MacMillan 2008); J. Murray (ed), Deleuze and Guattari: Emergent Law (Abingdon, Routledge 2011); J. de Ville, Jacques Derrida: Law as Absolute Hospitality: Law as Absolute Hospitality (Abingdon, Routledge 2012); T. Zartaloudis (ed), Giorgio Agamben: Power, Law and the Uses of Criticism (Abingdon, Routledge 2011); L. de Sutter \& K. McGee (eds), Deleuze and Law (Edinburgh, Edinburgh University Press 2012); L. de Sutter (ed), C. Butler (ed), Henri Lefebvre: Spatial Politics, Everyday Life and the Right to the City (Abingdon, Routledge 2012); Althusser and Law (Abingdon, Routledge 2013); P. Langford (ed), Roberto Esposito: Law, Community and the Political (Abingdon, Routledge 2015).

${ }^{4}$ L. de Sutter (ed), Žižek and Law (Abingdon, Routledge 2015). 
nexus of law and ideology from different angles. Most of the papers were presented at the $1^{\text {st }}$ International Workshop on Law and Ideology held in Wrocław, Poland; two of the papers come from the $2^{\text {nd }}$ International Workshop on Law and Ideology held in Sarajevo, Bosnia and Herzegovina.

Our original intent as conveners of the $1^{\text {st }}$ Workshop which sparked the present special issue was to invite Polish and foreign young legal theorists to focus on the legal implications of the theory of Slavoj Žižek, a Slovenian philosopher and cultural critic, who with equal ease and verve speaks of the Hegelian concept of negation, Hitchcock's films, and the differences between the German and French toilets. His language is full of paradoxes, jokes and thus breaks solidified dry, academic pseudo-scientific language, which also colonized legal theory.

Independently from each other, we both considered that an application of Žižek to law could be an interesting intellectual challenge. After discussion, we came to the conclusion that the part of his theory which would lend itself most easily to being applied within the legal domain is his critique of ideology, which was first formulated in his Sublime Object of Ideology ${ }^{5}$ and Tarrying with the Negative ${ }^{6}$, both published at the historic turn of the 1980 s and 1990s. Our choice of Žižek as the point in contemporary philosophy from which one could move, following Zirk-Sadowski's metaphor, towards law, is not accidental. According to Žižek ideology is no longer a matter of marches and banners but modern ideology is primarily a matter of personal pleasure (jouissance) and everyday practices. Since the body of law is made in practice, performed by its subjects, it is an ideal field of research and a symptom of ideology. The jouissance that lawyers find in the law is an underrated aspect of contemporary politics.

The idea of organising an academic event which would bring together Žižek and the law emerged during our discussions in Belfast where both of us attended the Critical Legal Conference 2013 on "Reconciliation and Reconstruction". ${ }^{7}$ In particular, we decided to organize the event in the form of a small workshop, furthering lively discussions and a direct exchange of ideas, and we chose Wrocław - the unquestionable capital of Polish critical legal theory - as the most suitable venue for the first event. Being aware of the fact that Žižek's critical theory is not a prime subject of interest for lawyers, even amongs members of the critical legal community, we decided to formulate the call for papers broadly enough to encompass all critical perspectives, such as the classical Marxist critique of ideology, the critical sociology of Pierre Bourdieu or the (post)structuralist approach of Louis Althusser. Nevertheless, we decided to give our workshop a precise theoretical outlook, calling it the "International Workshop on Law and Ideology', hoping that 'law \& ideology' would eventually join the world of such academic buzzwords as 'law and literature, 'law and the humanities' or 'law and politics'.

\footnotetext{
${ }^{5}$ S. Žižek, The Sublime Object of Ideology (London, Pluto Press 1989).

6 S. Žižek, Tarrying with the Negative: Kant, Hegel, and the Critique of Ideology (Massachussets, Massachussets Institute of Technology Press 1993).

7 Cf R. Mańko, J. Łakomy, 'Critical Legal Conference, Belfast, Irlandia Północna, 57.09.2013 r.' (2014) 8 Archiwum Filozofii Prawa i Filozofii Społecznej 88-91.
} 
We received and accepted a number of papers which interpreted the theme of the workshop from very different angles. ${ }^{8}$ A year later, we decided to continue the formula of the workshop, and organized, as a joint initiative of the University of Sarajevo School of Political Science and the University of Wrocław Centre for Legal Education and Social Theory (CLEST), the $2^{\text {nd }}$ International Workshop on Law and Ideology on "Memories of Struggles, Struggles of Memories" in Sarajevo. ${ }^{9}$ This time, owing to the growing reputation of the workshop, as well as the choice of a topic which, in that precise geographical setting, has a special significance, we had a difficult choice amongst a large number of submitted papers. The participants of the $2^{\text {nd }}$ Workshop examined the nexus of law and memory, in the optic of the critique of ideology, from various angles. The $3^{\text {rd }}$ International Workshop on Law and Ideology will be hosted on 23-24 May 2016 by the Tsereteli Institute of State and Law, Javakhishvili State University of Tbilisi (Georgia) in collaboration with the Centre for Legal Education and Social Theory of the University of Wrocław (Poland) and the Oñati International Institute for the Sociology of Law (Spain), under patronage of The Hague Journal on the Rule of Law. The topic selected for 2016 is "Constitutionalism, Rule of Law and the Politics of Conflict". The aim of the workshop will be do engage into a critical comparison of the liberal vision of conflict on the one hand, and the agonistic vision, represented inter alia by Chantal Mouffe and Ernesto Laclau, on the other.

This special issue of the Wrockaw Review represents a selection of papers devoted to the law and ideology nexus, approached from various angles. In the first paper, Hanna Dębska, by using the concepts of Pierre Bourdieu's critical sociology attempts to go beyond the limitations of the Marxist perspective. In the second paper, Rafał Mańko draws attention to a specific figure in Žižek's Lacanomarxist critique of ideology, namely the notion of ideological interpellation. Mańko argues that interpellation or - in Lacanian terms - capitonnage, quilting - is of crucial importance both for law and for ideology. Indeed, it is the mechanism through which law creates human subjects, thereby not only quilting them to its own ideological fabric, but also strengthening at the same time the hegemonic ideology of a given society. After a theoretical introduction, where Mańko traces the notion of ideological interpellation to Althusser, Mladen Dolar and finally Slavoj Žižek, he gives an overview of concrete examples showing that this theoretical tool can be easily 'operationalised', i.e. deployed directly in the ideological struggle. In the third paper, Michał Stambulski explores two ways to study the ideology of the law. The first, which can be found in the writings of Marx, is to examine the content of the law. It focused how certain legal provisions serve the interests of specific social groups. The second, initiated by Louis Althusser and continuated by Žižek, is to examine the forms of law.

\footnotetext{
${ }^{8}$ Cf R. Mańko, W. Kauczor, W. Zomerski, 'Conference Report: 1st International Workshop on Law and Ideology (Wrocław, 29-30 May 2014)’ (2015) 3 (2) Wrocław Review of Law, Administration and Economics 84-87.

9 Cf the workshop programme available online at: http://fpn.unsa.ba/bs/wpcontent/uploads/2015/05/Pravo-i-ideologija-program-konferencije.pdf, accessed February 2016. A conference report is forthcoming in the Wroctaw Review of Law, Administration and Economics.
} 
The form of law (eg. the form of liberal constitution) presents itself as a politically neutral when in fact it is associated with the hidden vision of the community and redistribution of capital.

These three general and theoretical papers are followed by a number of more specific ones, which explore concrete angles of the law and ideology nexus. Dace Šulmane addressed the issue of nationalism as the hegemonic legal ideology in Latvia. In her text she points out that following the fall of the Soviet Union, the official Soviet Marxist-Leninist ideology perished from this Baltic country, and its place was taken by nationalism. Sulmane traces the influence of ideology upon various fields of law, including especially the language laws favouring the Latvian language at the expense of Russian.

Lidia Rodak and Piotr Żak compared the traditional and the modern models of applying law, i.e. the the syllogistic model, based on subsumption, and the argumentative model, based on balancing principles. They came to the conclusion that the main difference between them has an axiological character.

The next section is devoted to the legal interpretation and aesthetics of law. Martin Škop ideology in law is reproduced by the preferred means of interpretation. In his opinion, it is related to the way in which the law is presented to the public, especially by popular culture. In her paper Markéta Klusoňovà seeks to expand legal argumentation on agruments from literary fiction. Resistance of the legal discourse on such arguments can be seen as ideological. In his article Wojciech Zomerski compares the concept of ideology in Marx and Žižek in the context of human rights and literature. As examples of literary works serve him: Adolus Huxley's Brave New World and George Orwell's Nineteen Eighty-four in which ideology obtains different forms.

Three papers focus on the historical aspects of the law and ideology nexus, including the relationship between law and social memory. A concrete example of legal ideology in its practical workings was explored by Anna Klimaszewska who focused on a French legislative act of the 17th century and its ideological underpinnings. Mirosław Sadowski in his paper tracks different dimensions of the notion of memory. The author pays attention especially to the literary and legal implications of social memory. The final paper, by Paolo Caroli, addresses the role of the judiciary within the construction of collective memory by referring to the example of post-fascit Italy.

We hope that the idea of the Workshops in the field of "law and ideology" field will not only continue to bring together scholars sharing a similar approach to legal theory, but also help to consolidate "law and ideology" as a distinct field of critical legal research. We believe that the law and ideology paradigm hides a lot of jouissance to yet to be explored. 